\title{
CICERO AND THE TRIAL OF VERRES ${ }^{1}$
}

\author{
J.E. Atkinson, University of Cape Town
}

\section{The legal background}

The legal remedy for extortion by a provincial governor was first provided - in a non-ad hoc way - by the Lex Calpurnia de rebus repetundis of $149 \mathrm{BC}$, which established a standing court (quaestio) of senators presided over by a praetor. The procedure prescribed by the Lex Calpurnia was legis actio sacramento, 2 in which plaintiff and defendant (here treated as two claimants) made their separate claims on oath (sacramentum) before a praetor, and the two sworn statements were then referred to a iudex for a decision (Gaius Institutes 4.13-17). Since legis actiones were the privilege of citizens, non-citizens would have been debarred from presenting their case directly to the extortion court.

This situation changed with legislation on extortion introduced in 123 and/or $122 \mathrm{BC}$, when Gaius Gracchus was a Tribune of the Plebs. This reform replaced legis actio sacramento with the procedure of nominis delatio, ${ }^{3}$ which was not reserved only for citizens, and a provision of the law was that a non-citizen who was successful in a suit before this court would be rewarded with citizenship. Thus the law permitted direct access to the extortion court by provincials who were not citizens.

The Gracchan legislation is more usually remembered as having transformed the composition of the jury, by taking entitlement to enrolment as jurors from the senators and entrusting the responsibility to those styled equites, or simply to those whose wealth was rated as above $400000 \mathrm{HS}$ (sesterces). 4 It is quite possible that it was this extortion law which created the definition of the equites as an ordo (status group) ranking below the senators. Whatever the legal definition, the equites were in simple terms those among Rome's wealthiest men who were not also senators. But the law and the subsequent history of the extortion court gave the equites a political identity. The motive of the legislator may have been simply to create an image of more impartial justice by stopping the practice whereby the defendant in an extortion case - an ex-magistrate and senator - was tried by fellow ex-magistrates and senators. The oaths and restrictions imposed on the jurors certainly imply a concern to establish a fair and proper judicial system.

The constitution of the court was changed several times after $122 \mathrm{BC}$, until Sulla included this matter in his programme of reforms (if that is the appropriate term). A lex Cornelia de repetundis of $81 \mathrm{BC}$ transferred the responsibility for jury service back to the senators. 5 So the matter rested till just after the trial of Verres, for in September $70 \mathrm{BC}$, L. Aurelius Cotta

1 My thanks to Dr. D. Wardle for his comments on an earlier draft of this paper.

2 Tabula Bembina line 23, available in the Loeb series in the volume Remains of old Latin, Vol 4, ed. E.H. Warmington, Cambridge (Mass.) 1940, esp. 316 sq. with Richardson (1987): esp. p.4).

3 Tabula Bembina parr. 1-3, 76 sq.; further on the text, Mattingly 1969:129-143.

4 Gaps in the Tabula Bembina parr. 12-13 and 16 do not allow us to reconstitute the legal definition of the new class of jurors, but the law certainly precluded senators from serving as jurors (16). Pliny Natural History 33.34 makes it more likely that the Acilian law lay down a property qualification for jury service, and that the label Equites was attached to this class of citizens later; cf. Badian 1972:135, n. 68.

5 Cicero In Verrem 1.37 and 47; Pro Rab. Post 9. 
carried a bill to have jury service shared by mixed panels of senators, equites and tribuni aerarii.

But the Sullan reform retained that key element of the Gracchan bill which allowed noncitizens direct access to the court. Thus Cicero was able to say of the law in the context of the trial of Verres:

When citizens have money snatched from them, the amount is claimed back in a civil action and in terms of private law. But this is the act for our allies; this is the law of foreign peoples.

(Divinatio in Caecilium 17-18)

\section{The procedure}

Sicilians initiated an action through an advocate by laying charges before a praetor. A medieval commentator on Cic. In Verrem 1.5 stated that if Verres had remained silent (tacuisset), guilt would be assumed and the hearings would switch to a litis aestimatio, for the assessment of damages, but if the accused defended himself then the case was referred to the (sc. Extortion) court. In general in Roman criminal law, the accused could not delay matters by not turning up to answer charges in a court, a principle which did not apply in civil law. But the procedure of the Extortion Court worked more like that of a civil, than of a criminal court, thus Crook (1987: esp. 41) has suggested that the commentator should have said that if Verres had confessed to extortion, then guilt would have been established, and the matter would have been referred for the assessment of damages.

To get back to the narrative, Sicilians approached Cicero to plead their case, and in January $70 \mathrm{BC}$ he applied by postulatio to the praetor, $\mathbf{M}^{\prime}$. Acilius Glabrio, for an action against Verres. But Verres was working to have his own agent (praevaricator: a false accuser) appointed as prosecutor, and so the issue was tested before a jury court by divinatio, 6 a legal procedure designed to prevent collusion between the accused and a prosecutor. Q. Caecilius Niger was defeated at this round, and Cicero could begin his attack on Verres. In the praetor's court he charged Verres with having extorted some 40 million HS7 in Sicily, and the praetor was asked to grant nominis receptio and to set a trial date.

The trial proper (actio) dealt with the charges and Cicero's task was to establish that Verres had extorted money in violation of the Lex Repetundarum.

The trial itself was divided into two stages. In the actio prima the plaintiff presented his case, during which he might introduce relevant documents. Then witnesses were summoned and the rival advocates would debate the issues and examine the witnesses. Then after a break of at least one day, 8 the actio secunda was held, when the advocates made their concluding speeches.

If the trial resulted in condemnatio, the matter was then advanced to the litium aestimatio, for the determination of the value of the claims.

6 Gellius 2.4; Cic. Pro Plancio 46; Divinatio in Q. Caecilium 10; on collusion (praevaricatio) as an offence, Tabula Bembina par. 75.

7 HS means sestertius. As a rule of thumb 3 HS represented a workman's daily wage, thus if a semiskilled artisan in an institution not totally unknown to me may eam $R 60$ per day, then a sestertius might be said to be worth twenty Rands. Any such calculation has little scientific value, but may serve to indicate the order of magnitude of Verres' rackets.

8 The statutory adjournment (comperendinatio) was a requirement introduced by the Lex Glaucia of c. 101 BC. (Cic. In Verr. 2.1.26). 
The extortion trial procedure was a little curious, in that it dealt with a criminal offence - to take money unlawfully (exigere ... adversus leges: 3.194 ), but was conducted more like a civil action.

The actio prima began on 5 August and lasted nine days (In Verr. 2.1.156; In Verr. 1.31). There had to be a statutory adjournment (comperendinatio), and Cicero's desire was to fit the continuation in before 16 August, when the Ludi votivi (Pompey's games) were to start (In Verr. 1.34). Verres' supporters were planning a filibuster to have the conclusion of the trial heid over to $69 \mathrm{BC}$, when Q. Metellus Creticus would be one of the consuls, and M. Metellus was to hold a praetorship with the presidency of the Extortion Court as his allotted responsibility (Cic. In Verr. 1.21).

During the actio prima Hortensius seems to have spoken for Verres, 9 although Plutarch states that Hortensius abandoned the defence and only spoke for Verres when the case came to the litis aestimatio stage (Cic. 7.8).

Though Cicero in the actual proceedings variously claimed that Verres had extorted 100 million, or 40 million, sesterces (Coec. 19 and In Verrem 1.56), Plutarch (Cicero 8.1) says that the result was a determination of 3 million $\mathrm{HS}$ as the amount Verres was to repay.10 There may have been some horse-trading in that Cicero (In Verr. 2.1.14) indicated that if he did not gain a conviction, he would prosecute Verres again in 69 while he was aedile. Thus Verres may have been ready to accept an unfavourable verdict in 70 with a low settlement figure in return for an assurance that no further action would be taken against him. Plutarch (Cicero 8.2) adds that Cicero was the target of libellous accusations that he had accepted a bribe to reduce the level of damages claimed.

As for those who sat in judgement on Verres, though the trial took place as late as August 70 , the jury panel was still made up exclusively of senators, according to the Cornelian law.11 In terms of the Lex Acilia the jurors were chosen for the Extortion Court from a panel of 450 . This number was reduced to 100 by the choice of the plaintiff, and the defendant was then allowed to pick 50 from the 100 to act as his iudices (Lex Acilia 24-25). But the panel could be further reduced by the exclusion of anyone whose appearance as a juror might be prejudicial in the immediate trial.

\section{Verres' scams}

Verres was able to amass a fortune by extortion in Sicily despite the existence of strict legislation against such an abuse of power and a legal mechanism for those exploited to seek redress, and despite the senatorial tradition of clientela (patronage), which obliged those who were empowered to give protection to those who sought assistance. Verres as governor had power, and the force to get his own way, since Sicily, like any province, was effectively under martial law. The system for collecting taxes and tithes was supposed to preclude extortion, but could be subverted, if there was collusion between the governor and the publicani who contracted to collect the dues.

The Roman system of collection of tithes and taxes in the provinces largely depended on financiers who contracted to do this work for the Republic. The contracts for the collection of tithes on corn in Sicily were still issued in Sicily, but the contracts in respect of tithes of

9 Quintilian 10.1.23; M.C. Alexander, Hortensius' speech. 1976.

10 The penalty was usually double the value of the assessed total amount extorted: Tabula Bembina par. 59. Thus Plutarch may mean that Verres stood to repay 6 million HS.

11 Cicero In Verrem 1.31, 38 and 44. 
wine, olive oil and fruit, and of harbour dues were by Verres' time as governor awarded in Rome. Every five years the censors in Rome called for tenders for the collection of the various taxes in the provinces, and companies of financiers (publicani) bid for the business. Contracts for specific taxes in specific provinces would be issued, and the Roman publicani would then work through officials, styled pro magistro in the provinces. The provincial officers may have been variously employees of the principals in Rome or sub-contractors. The provincial publicani might further sub-contract to publicani at the local level. A company that secured such a contract had to have sufficient capital to underwrite the business, as it would have to produce each instalment according to its original tender by the due date. Thus the Roman treasury was assured of its revenue income, and the publicani, as entrepreneurs, carried the risk.

In ideological terms these publicani were public-spirited financiers, providing a service for the Republic, and hence were not supposed to be profiteering. They were tacitly allowed to take a small percentage towards their expenses, 12 but the real opportunity for exploitation came with their freedom to advance funds to provincials to meet their tax obligations. Interest rates might be as high as $48 \%, 13$ which was an attractive incentive to investment in the patriotic business of revenue collection.

The Roman publicani were generally equites, and in theory there was no collusion between senatorial governors of provinces and the publicani who were there to collect tithes and taxes: the governor was supposed to give due support and protection to the tax-gatherers, but he was also to protect the provincials from illegal and unfair practices. 14

But, as happened in Verres' case, there might well be collusion between publicani and the governor. Apronius, the chief tithe collector, admitted that he was a business partner with Verres, and was resentful that Verres was taking a disproportionate percentage of the profits.15 The local collectors of tithes in Sicily were known as decumani, and it was common knowledge that Verres was effectively their employer.16

The misery of the Sicilian farmers may have been intensified by the fact that the obligations were determined individually, and not, as in other provinces, community by community. In Sicily there was no cushioning between the individual and the decumanus.

Sicilian farmers were under obligation to offer up a tithe (decuma) of their corn harvest, and might be asked to hand over an equivalent amount of grain, but this time in exchange for a modest payment. They might be asked to sell further amounts of corn to Rome at a slightly higher price. A catch in this system was that the governor might direct a farmer to deliver his grain to a specific depot or granary, which might be a considerable distance away. To avoid the transport costs, the farmer might be allowed to pay the tax collectors an amount in lieu of the grain, so that the officials might buy the requisite grain from another source.

Verres abused this system with a variety of scams: by obliging farmers to deliver grain to distant points in Sicily he forced them into commuting the tithe for cash payments; he then set a purchase price on the corn way above the going market rate - thus a farmer might be obliged

12 Cic. In Verrem 2.3.181ff.

13 Cic. Ad Atticum 6.1.5: the most notorious case is linked with that champion of human rights, $M$. Junius Brutus; the key figure in this line of business in Verres' Sicily was Carpinatius: Cic. In Verrem 2.2.186ff.

14 Verres had to uphold the provisions of the Lex Rupilia - the law of 132 BC, which established new rules for the administration of Sicily; and his own edict threatened any dishonest collector with an eight-fold penalty: Cic. In Verr. 2.3.26. 
to buy corn in lieu of his tithe for $12 \mathrm{HS}$ per modius, against a market rate of $3 \mathrm{HS}$ or less.17 As for grain purchased for the Roman state, Verres had funds from the Senate to buy at $4 \mathrm{HS}$ per modius. He could have bought at $3 \mathrm{HS}$ per modius and refunded the credit balance to the treasury in Rome, or he could have helped the Sicilian farmers by buying their grain at $4 \mathrm{HS}$, which would have been better than the going market rate. He was able to buy grain on the market for as little as 2 HS per modius, and was then able to make a profit in two ways. First he could report back to Rome that he had purchased grain at $4 \mathrm{HS}$, and keep the difference, and secondly, by selling grain at $12 \mathrm{HS}$ to farmers who asked for commutation of their tithe into cash payments, he could make a notional profit of $8 \mathrm{HS}$ on each modius sold in this way. 18 Put another way, the situation could arise where a farmer had to sell corn at $2 \mathrm{HS}$ per modius to raise cash to "buy" grain elsewhere in Sicily for $12 \mathrm{HS}$ for delivery to a Roman granary.

Other scams included the straightforward extortion of amounts over and above the tithe obligation, and the demand for money in return for the suppression of incriminatory evidence, whether real or fictitious (In Verr. 2.5.15).

\section{The hidden agenda}

The trial took place in the consulships of Pompey and Crassus, who owed their magistracies to what was effectively a coup d'etat. In 71 both had been in command of armies engaged in the final stages of the suppression of the slave revolt led by Spartacus. Crassus was not entitled to bid for the consulship before the elections held in 70 for the year 69, and Pompey was too young to qualify for the office (cf. Appian Civil Wars 1.121).

Thus in 70 Pompey in particular was looking for issues to justify his unconstitutional seizure of power, and it was in that context that he lent his support to the prosecution of Verres. Pompey was thus able to pose as the champion of clean government, supporting oppressed provincials, stamping out abuse of the judicial system (In Verrem 1.45), challenging corruption in the Senate, defending the treasury, averting rebellious movements in Sicily, confronting Senatorial monopoly in the law courts. He could also claim to be true to the Roman tradition that the ties of clientship imposed on patrons the solemn obligation to render assistance when called on by their clients. One of Verres' victims was Sthenius, who had ties of clientship with Pompey (In Verrem 2.2.83ff.).

Another element in the context of the trial relates to the war in Asia in which Roman troops were pitted against the resistance movement led by Mithradates of Pontus (on the southern coast of the Black Sea). The earlier phase of the war which began in 88 , ended with the return to Italy of Sulla in 83, who then initiated a bloody coup d'etat and once in power as dictator in 81 introduced the proscriptions, which provided a legal framework for the systematic liquidation of his surviving political opponents. Pompey was associated with Sulla in these events, and the senators were thereafter naturally hesitant to entrust him with any commission outside Italy lest he follow his mentor's horrendous example. But in 77 the Senate was obliged to commission Pompey to take the troops under his command to reinforce, the Roman army in Spain, which was campaigning against Sertorius. Pompey left for Spain in 76. Sure enough in 74 he threatened a coup unless his demands to the Senate for supplies and money for wages were met.19 In the same year the Senate faced a new crisis in Asia, and sent the two consuls to wage war against Mithradates. The consul who was awarded the province of Cilicia as his base for the action against Mithradates was L. Licinius Lucullus, who belonged, on his

17 Cic. In Verr. 2.3.191sq.

18 Cic. In Verr. 2.3.195sq.

19 Plutarch Pompey 20.1; Lucullus 5.1; Sallust Historiae 2.98. 
mother's side, to the Metellan family. The significance of this family connection will require further comment.

Lucullus supported Pompey's request for cash in 74, but that was to keep him in Spain, because he wanted the command against Mithradates, and knew that Pompey would have preferred to leave Spain and to head the Roman forces in Asia.20 It appears that the Senate saw the raising of an army to fight in Asia as an opportunity to build up a force that could be used to counter Pompey, if he tried to take Rome by force. We may assume that Pompey was decidedly irritated with Lucullus, and did eventually take over his command in Asia in 66.

In the year of Pompey's consulship Lucullus was anything but finished with the war against Mithradates, and a storm broke when it became known that Lucullus had introduced a number of measures to enable communities in Asia to lessen the burden of their indebtedness to Roman financiers, who had lent them money to pay reparations imposed more than ten years earlier by Sulla. Lucullus' new regulations included a limit on interest rates and provisions that the total amount of interest exacted was not to exceed the value of the original loan, and that the annual repayment charge was to be limited to $25 \%$ of the debtor's income (Plutarch Lucullus 20.3). Equestrian financiers and publicani in Rome were horrified at this attack upon the free operation of the money-lending business. Against this background, Pompey's promotion of the case against Verres might be seen as a way of demonstrating support for Rome's financiers in their legitimate operations.

Rivalry between Lucullus and Pompey must also be set in the context of senatorial politics. Licinius Lucullus was the son of a Metella, and married a Clodia, who was the daughter of a Metella, from another wing of the family. His mother-in-law was a cousin of Quintus and Lucius Metellus, respectively the consul-elect for 69 , and the governor of Sicily in 70 , who both played important roles in supporting Verres against his accusers. It is quite possible that the Metelli brothers had benefited from Verres' tenure of the governorship of Sicily as they faced heavy bills for buying votes in the elections of $70 \mathrm{BC}$. They presumably felt some obligation to assist Verres.

Another prosopographical detail that might be relevant is that Verres' defence advocate, $Q$. Hortensius Hortalus (consul $69 \mathrm{BC}$ ) was related to $\mathrm{Q}$. Catulus (a consul in $78 \mathrm{BC}$ ). Catulus was the son of Marius' co-commander against the Cimbri and Teutones, and the elder Catulus had distanced himself from Marius. The younger Catulus had influence with Sulla (In Verrem 2.4.37), and defended Sulla's system against the radical Lepidus in 78. Cicero lauds him as a pillar of respectability (e.g. In Verrem 2.3.210-211), and clearly wanted to detach him from the Metellan faction and Hortensius. If Catulus was to merit his standing as a Senate leader, he would have to give up his support for Metellan factionalism.

Incidentally, Cicero makes clear why Hortensius defended Verres. After the elections in 70, when Hortensius gained a consulship for $69 \mathrm{BC}$, Gaius Curio made a point of noisily congratulating Verres on Hortensius' election: "I hereby declare that the result of today's election is that Verres is acquitted" (Cicero In Verrem 1.18).

The political context of the trial in terms of the position of the Senate was the imminence of a debate about the composition of the jury courts and Pompey's commitment to restoring the power of the Tribunes of the Plebs. The Sullan edifice was crumbling, and the Senate could not hope to block the return to more popularist politics and a more liberal constitution. Thus much rode on the vote which the senatorial jurors were to give in the case against Verres. As Strasburger (1956:28) noted, Cicero presented his case in the Verrine speeches not so much as a friend of business interests or as a popularis (a reformist), but as a senator addressing his 
peers. Would the senatorial jurors allow a Verres to subvert their authority in matters of finance and foreign affairs? Verres had to go.

\section{BIBLIOGRAPHY}

Alexander, M.C. 1976. "Hortensius' speech." Phoenix 30, $46 \mathrm{ff}$.

Badian, E. 1958. Foreign Clientelae. Oxford: Oxford University Press.

Badian, E. 1972. Publicans and sinners. Oxford: Blackwell.

Crook, J.A. 1987. "Was there a doctrine of manifest guilt?" Proceedings of the Cambridge Philological Society 213, $38 \mathrm{ff}$.

Gruen, E. 1974. The last generation of the Roman Republic. Berkeley: University of California Press.

Lacey, W.K. and Wilson, B.W.J.G. 1970. Res Publica: Roman politics and society according to Cicero. Oxford: Oxford University Press.

Levens, R.G.C. 1946. Cicero, the fifth Verrine Oration. London: Methuen (reprinted Bristol Classical Press, 1980).

Marshall, A.J. 1967. "Verres and judicial corruption." Classical Quarterly 17, 408-413.

McDermott, W.C. 1977. "The Verrine jury." Rheinisches Museum 120, 64-75.

Pritchard, R.T. 1971. "The Lex Calpurnia de repetundis." JRS 77, 1-12.

Sherwin-White, A.N. 1952. "The extortion procedure again." JRS 42, 43-55.

Strasburger, H. 1956. Concordia Ordinum. Amsterdam: Hakkert (reprint of the original edition of 1931). 